\title{
Partial traumatic amputation of an upper limb with excellent functional recovery: A 13-year follow-up clinical case
}

\author{
Amputación traumática parcial de una extremidad superior con excelente recuperación \\ funcional: un caso clínico de 13 años de seguimiento
}

Lorenzo Franco-de la Torre', José R. Villafán-Bernal', Martha C. Díaz-Franco, Esperanza Padilla-Martín ${ }^{4}$, Raúl Franco-Díaz de León ${ }^{5}$, Mario A. Isiordia-Espinoza ${ }^{6}$ and Sergio Sánchez-Enríquez, ${ }^{6,7 *}$

${ }^{1}$ Departamento de Ciencias de la Salud, Centro Universitario de los Altos, Universidad de Guadalajara, Jalisco; ${ }^{2}$ Departamento de Cirugía, Cátedras CONACYT, Universidad Autónoma de Aguascalientes, Aguascalientes; ${ }^{3}$ Departamento de Oncogenómica, Instituto Nacional de Medicina Genómica, Ciudad de Mexico; ${ }^{4}$ Sanatorio Médico Quirúrgico de los Altos, Jalisco, México; ${ }^{5}$ Centro de Ciencias de la Salud, Universidad Autónoma de Aguascalientes, Aguascalientes; ${ }^{6}$ Departamento de Clínicas, Centro Universitario de los Altos, Universidad de Guadalajara, Jalisco; ${ }^{7}$ Departamento de Biología Molecular y Genómica, Centro Universitario de Ciencias de la Salud, Universidad de Guadalajara, Jalisco. México

\begin{abstract}
Introduction: There are just a few reports that deal with long-term outcomes of a partial amputation surgical repair. Long-term studies have reported similar rates of disability among patients with amputations and those that have been undergoing reconstructive surgery. Objective: The purpose of this report is describing a clinical case of a patient with partial traumatic amputation of an upper limb with an excellent functional recovery after 13 years of follow-up. Clinical case: The case of an 8 year old male patient with severe trauma to the upper left limb is described. The lesions included an oblique diaphyseal open fracture of the distal region of the humerus, along with detachment of the biceps and triceps muscles. The fracture was fixed transiently with $2.0 \mathrm{~mm}$ Kirschner's wire followed by immobilization with Sarmiento's brace, and finally, open reduction and internal fixation with a $3.5 \mathrm{~mm}$ dynamic compression plate were performed. The muscular and neurovascular integrity allowed microsurgical repair of the radial nerve and neuromuscular rehabilitation. Conclusion: This clinical report represents a case with an excellent functional recovery witnessed through a 13-year follow-up period.
\end{abstract}

KEY WORDS: Partial traumatic amputation. Upper limb. Functional recovery.

\section{Resumen}

Introducción: Se han publicados pocos informes sobre el seguimiento a largo plazo de la reparación quirúrgica de una amputación parcial. Algunos estudios de largo plazo han registrado tasas similares de discapacidad entre los pacientes con amputaciones y los sometidos a operación reconstructiva. Objetivo: Informar un caso clínico de una amputación traumática parcial de una extremidad superior con recuperación funcional después de 13 años de seguimiento. Caso clínico: Paciente masculino de ocho años con traumatismo grave en la extremidad superior izquierda, desprendimiento de los músculos bíceps y tríceps y una fractura diafisaria oblicua del húmero distal. La fractura se fijó de manera transitoria con alambres de Kirschner de $2.0 \mathrm{~mm}$, seguido de inmovilización con aparato de Sarmiento y al final se realizó reducción abierta y fijación interna con placa de compresión dinámica de $3.5 \mathrm{~mm}$. La integridad muscular y neurovascular permitió la reparación microquirúrgica del nervio radial y la rehabilitación neuromuscular. Conclusiones: Este informe clínico representa un caso de una recuperación funcional excelente atestiguada a través de un periodo de seguimiento de 13 años.

PALABRAS CLAVE: Amputación traumática parcial. Extremidad superior. Recuperación funcional.

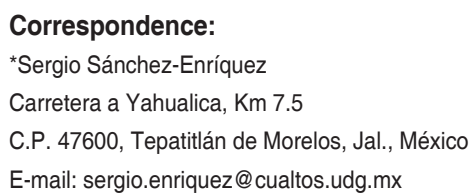

Date of reception: 03-09-2018

Date of acceptance: 10-06-2019

DOI: $10.24875 / C I R U .19000695$
Cir Cir. 2019;87(S1):43-47

Contents available at PubMed www.cirugiaycirujanos.com 


\section{Introduction}

An amputation is the traumatic or surgical separation of a limb or appendage from the body. Traumatic amputations usually occur in contaminated environments as a result of severe trauma ${ }^{1}$. The estimated number of traumatic amputations per year is 30,000 around the globe being $65 \%$ of the upper limb amputations. Males aged 15-40 represent the highest incidence group. The estimated medical care cost of traumatic amputations is approximately $7.7 \%$ of the Gross Domestic Product of the United States of America ${ }^{2}$.

Complete amputations are characterized by loss of continuity between the amputated region and the body. While in partial amputations, the anatomical continuity persists, either through tendons, ligaments, or muscles. The key difference between partial amputations and severe lacerations resides in the percentage of soft tissue maintain continuity ( $£ 25 \%$ in partial amputations). Partial amputations are classified using the Gustilo-Anderson classification (same as for open fractures) depending on the severity of the trauma and contamination degree ${ }^{3,4}$.

There are just a few reports that deal with long-term outcomes of partial amputation surgical repair. War veterans case reports show that most of the patients lead normal, productive lives with no relevant limitations after lower limb amputations; however, those with upper limb amputations tend to be severely disabled. The main causes of disability are decreased functionality and mood/anxiety disorders. Long-term case studies have reported similar rates of disability among patients with amputations and those that have been undergoing reconstructive surgery. In fact, only $30 \%$ of patients are able to resume their professional activities after 2 years ${ }^{5-7}$.

The purpose of this report is describing a clinical case of a patient with partial traumatic amputation of an upper limb with an excellent functional recovery after 13 years of follow-up.

\section{Case report}

An 8-year-old male patient with severe trauma by getting his left arm jammed in the motor bands of a forage grinder received emergency medical care at the Sanatorio Médico Quirúrgico de los Altos from Tepatitlán de Morelos, Jalisco, México. The patient got an open fracture in the left arm at the junction of the middle third to the distal humerus (Fig. 1) and section

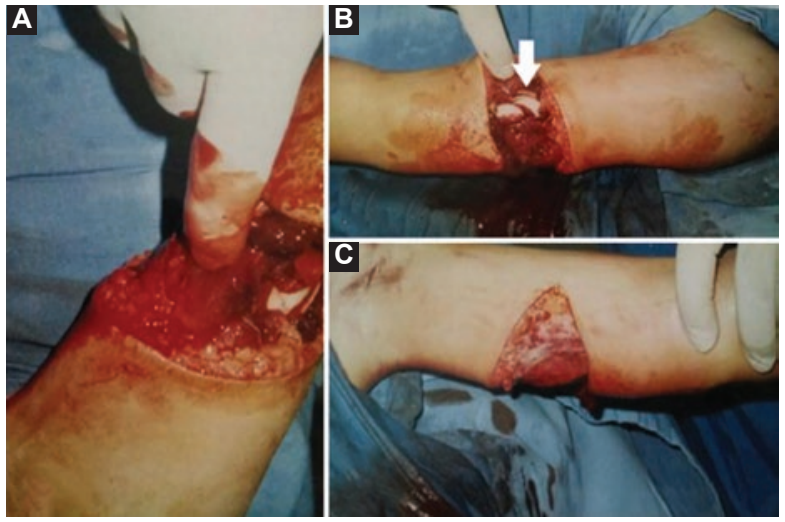

Figure 1. A: Surgical exploration with a loss of more than $75 \%$ in the soft tissue as well as avulsion of the biceps and triceps muscles. B: Oblique fracture of humeral bone and the entire brachial neurovascular bundle (arrow). C: The continuity in the brachial muscle is observed.

of the triceps and biceps muscles leaving the brachialis muscle intact. During surgical exploration, the brachial neurovascular bundle was apparently intact (Fig. 2). The bony fragments were stabilized using 2.0 $\mathrm{mm}$ Kirschner wires that were introduced in a retrograde fashion through the humeral medullary cavity and coming out on the shoulder. The open reduction was performed and the nails were pulled back $3 \mathrm{~cm}$ to stabilize the fragments. Subsequently, biceps and triceps muscles were repaired. Finally, the subcutaneous tissue and the skin were sutured. During the post-anesthetic recovery period, the patient showed inability to extend the wrist, which was expected after the neurovascular bundle manipulation during reconstruction. Once stable and lucid, a Sarmiento brace was applied to immobilize the limb.

During the first 3 weeks after surgery, the extension of the patient's wrist showed no signs of improvement, so an electromyography was performed that reported severe axonotmesis of the left radial nerve. A wrist extension splint was placed in the damaged hand to facilitate cylindrical grip. Furthermore, transcutaneous electrical nerve stimulation (TENS) was applied twice a day, 10 min per session. Since there was no clinical improvement after 1 month of electrostimulation, we performed microscopic surgical exploration of the radial nerve with the help of a peripheral nerve surgery specialist. During the procedure, a slight rupture of the epineurium was evidenced including rupture of fascicles and perineurium (neurotmesis Grade V according to Sunderland classification) ${ }^{8}$. The injury was repaired with 10-0 and 12-0 nylon suture.

The rehabilitation with TENS continued after nerve microsurgery in combination with the use of a wrist extension splint. At 6 weeks, progressive regain of 

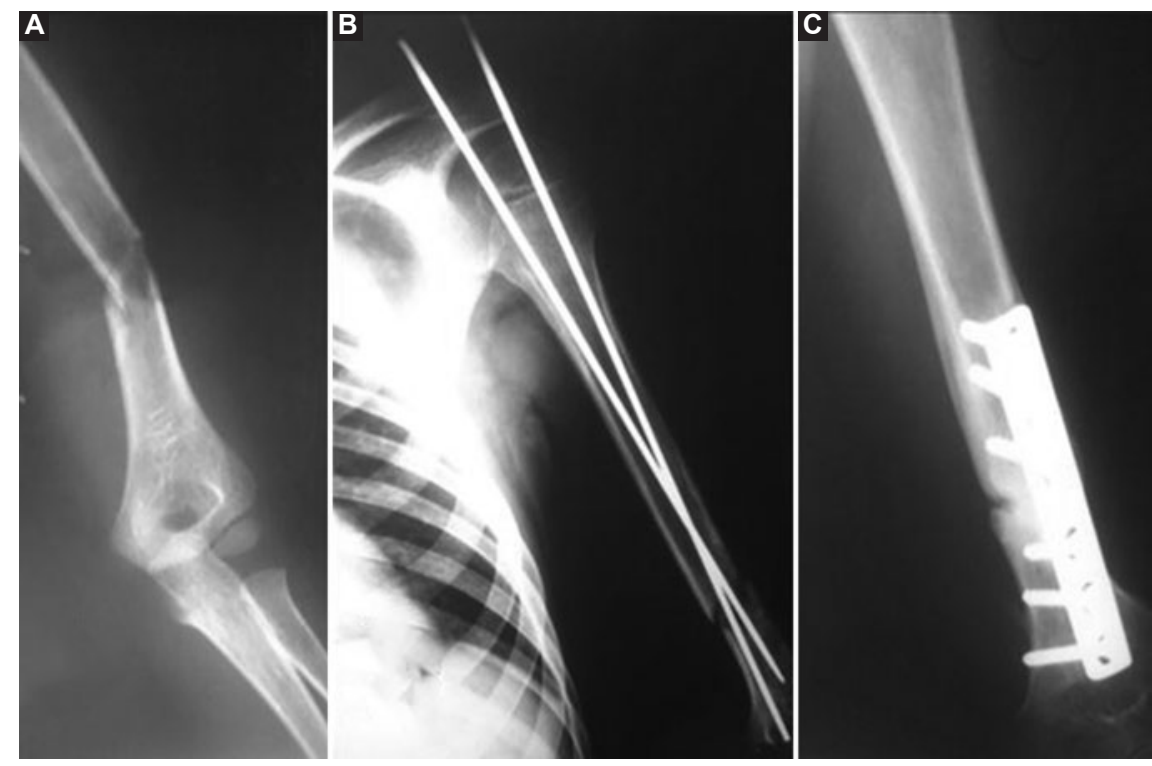

Figure 2. A: Pre-surgical X-ray showing a humerus oblique fracture of the patient. B: Smooth Kirschner wires were used to stabilize the fracture and make soft tissue reparation. C: Control $X$-ray after nerve and soft tissue repair.
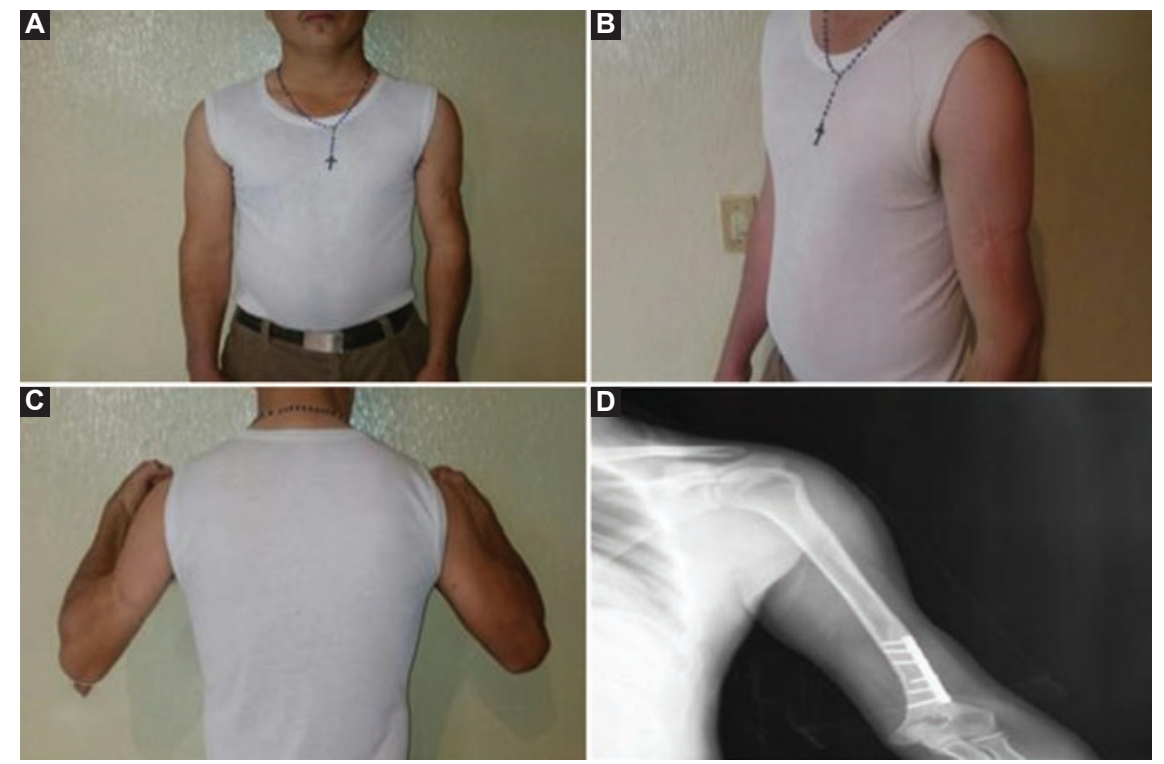

Figure 3. A-C: Patient after 13 years. Though hypotrophic, integrity, and functionality of the left upper limb are present. D: Latest X-ray photography 13 years after surgical repair.

sensory perception and movement of the wrist were evident and complete neurological recovery was achieved at 5 months.

The Kirschner wires were removed during the second surgery to facilitate rehabilitation exercises for biceps and triceps as well as TENS therapy. However, the patient developed horse hoof hypertrophic pseudoarthrosis; thus, the Sarmiento's brace was removed and the patient underwent surgery to repair the pseudoarthrosis. The medullary space was recanalized and a dynamic compression plate of $3.5 \mathrm{~mm}$ with six holes was used for fixation. Union occurred 3 months later.
At present, the patient is 21 years old; he works and performs activities of daily life without any limitations (Fig. 3). Physical examination of the affected limb reveals muscular hypotrophy; however, sensitivity, muscular strength, and ranges of motion of the left arm are clinically preserved.

\section{Discussion}

Our clinical and research team conducted a critical review of literature, noting that partial amputations in children are not common and their long-term follow-up 
is not either. According to the reviewed literature, we consider that this is the report of a partial amputation in a child with the longest period of clinical follow-up with the excellent functional results.

The management of partial amputations remains rather unclear in the field of reconstructive surgery 9 . At present, there is lack of consensus on both the criteria and techniques for reconstruction because the functional outcomes tend to be poor ${ }^{10,11}$. There are various ways to manage partial amputations of the limbs and all depend on the viability of the extremity, surgical team's expertise, resources, and rehabilitation availability ${ }^{12}$. When the limb is not viable or the hospital does not have the required personnel and/or resources, complete separation of the affected extremity followed or not by prosthesis adaptation is the usual management. This approach has great psychosocial impact due to disability, job loss, and poor functioning in daily activities ${ }^{13}$. The repair of the damaged extremity with fracture stabilization is another approach which requires the participation of an experienced multidisciplinary team including specialists in trauma, orthopedics, vascular surgery, and neurosurgery ${ }^{14}$. The most important criteria for therapeutic decision are the integrity of neurovascular bundle since its integrity prevents extensive bleeding (reducing the risk of hypovolemic shock), ischemia below the lesion and allows functional recovery of the affected limb. When the neurovascular bundle's integrity is lost, it has been reported failure rates ranging of $60-100 \%{ }^{15}$.

We are well aware that the management here presented is not the standard approach to partial amputation surgical repair, particularly when the Kirschner wires are used for internal fixation. However, the nearest trauma center was $3 \mathrm{~h}$ away. Motivated by the macroscopically intact neurovascular bundle and the patient age, our surgical team decided to go for limb repair with the available resources of our general hospital instead of transferring and risking the limb's viability.

Two events required surgery after the initial operation. The first one was radial nerve palsy, initially attributed to the manipulation of the neurovascular bundle during reparation; however, this did not resolve after 12 weeks so microsurgery was performed. Neurotmesis is a common complication of this kind of lesions and requires timely evaluation and precise repair $^{16}$. The second one was the development of pseudoarthrosis, which is a known complication of open fractures ${ }^{17}$.
This is an exceptional case since the reconstruction of partially amputated upper limbs is usually associated with poor outcomes in most reports ${ }^{18}$. Several factors could account for this outcome being the most relevant the linear, non-rotated fracture, and the little amount of soft tissue crush injury. Moreover, the close medical surveillance and timely interventions were crucial in the patient's recovery. The Zhong-Wei et al. criteria could be used to assess the functional recovery in this kind of clinical cases. These criteria are the following: (1) ability to work, (2) range of joint motion, (3) recovery of sensibility, and (4) muscular power ${ }^{19}$. The functional recovery in our clinical case could be qualified like "excellent" in all the points of the ZhongWei et al. criteria.

\section{Conclusion}

In the surgical management of partial amputations, the key factors that make reconstruction an option are small amount of soft tissue damage and integrity of the neurovascular bundle. In addition, the human and economic resources of the center managing the case with close patient follow-up tip the scale toward a more positive outcome ${ }^{20}$. This clinical report represents a case with an excellent functional recovery witnessed through a 13-year follow-up period.

\section{Conflicts of interest}

The authors declare that they have no conflicts of interest concerning this article.

\section{Acknowledgments}

"We thank the patient and his parents for signing the written consent and allowing the publication of this clinical case." This work was done without any financial support.

\section{Ethical disclosures}

Protection of human and animal subjects. The authors declare that no experiments were performed on humans or animals for this study.

Confidentiality of data. The authors declare that they have followed the protocols of their work center on the publication of patient data.

Right to privacy and informed consent. The authors have obtained the written informed consent of the patients or subjects mentioned in the article. The 
corresponding author is in possession of this document.

\section{References}

1. Skinner HB, McMahon PJ, editors. Musculoskeletal Trauma Surgery. In: Current Diagnosis and Treatment in Orthopedics. $5^{\text {th }}$ ed., Ch. 2. New York: McGraw-Hill; 2014.

2. Andersson G. American Academy of Orthopaedic Surgeons. $3^{\text {rd }}$ ed. Rosemont, IL: United States Bone and Joint Initiative: the Burden of Musculoskeletal Diseases in the United States (BMUS); 2014.

3. Gustilo RB, Mendoza RM, Williams DN. Problems in the management of Type III (severe) open fractures: a new classification of Type III open fractures. J Trauma. 1984;24:742-6.

4. Gustilo RB, Anderson JT. Prevention of infection in the treatment of one thousand and twenty-five open fractures of long bones: retrospective and prospective analyses. J Bone Joint Surg Am. 1976;58:453-8.

5. MacKenzie EJ, Bosse MJ, Pollak AN, Webb LX, Swiontkowski MF, Kellam JF, et al. Long-term persistence of disability following severe lowerlimb trauma. Results of a seven-year follow-up. J Bone Joint Surg Am. 2005;87:1801-9.

6. Bosse MJ, MacKenzie EJ, Kellam JF, Burgess AR, Webb LX, Swiontkowski MF, et al. An analysis of outcomes of reconstruction or amputation after leg-threatening injuries. N Engl J Med. 2002;347:1924-31.

7. MacKenzie EJ, Bosse MJ, Kellam JF, Burgess AR, Webb LX, Swiontkowski MF, et al. Characterization of patients with high-energy lower extremity trauma. J Orthop Trauma. 2000;14:455-66.

8. Sunderland $\mathrm{S}$. A classification of peripheral nerve injuries producing loss of function. Brain. 1951;74:491-516.

9. Bosse MJ, MacKenzie EJ, Kellam JF, Burgess AR, Webb LX, Swiontkowski MF, et al. A prospective evaluation of the clinical utility of the lower-extremity injury-severity scores. J Bone Joint Surg Am. 2001;83:3-14

10. Goodman RS. The Type-IIIC tibial fracture. Salvage or amputation. J Bone Joint Surg Am. 1988;70:311.

11. Smith DG, Castillo R, MacKenzie E, Bosse MJ, Group TL. Functional Outcomes of Patients who have Late Amputation after Trauma is Significantly Worse than for those who have Early Amputation. Salt Lake City: orthopaedic Trauma Association Annual Meeting; 2003.

12. MacKenzie EJ, Bosse MJ, Kellam JF, Burgess AR, Webb LX, Swiontkowski MF, et al. Factors influencing the decision to amputate or reconstruct after high-energy lower extremity trauma. J Trauma. 2002;52:641-9.

13. Hierner R, Berger AC. Long-term results after total and subtotal macroamputations of the upper limb. Eur J Plast Surg. 2005;28:119-30.

14. Sherman R. To reconstruct or not to reconstruct? N Engl J Med. 2002; 347:1906-7.

15. Martins RS, Bastos D, Siqueira MG, Heise CO, Teixeira MJ. Traumatic injuries of peripheral nerves: a review with emphasis on surgical indication. Arq Neuropsiquiatr. 2013;71:811-4.

16. Grinsell D, Keating CP. Peripheral nerve reconstruction after injury: a review of clinical and experimental therapies. Biomed Res Int. 2014;2014:698256.

17. Hesse B, Gächter A. Complications following the treatment of trochanteric fractures with the gamma nail. Arch Orthop Trauma Surg. 2004;124:692-8

18. Tintle SM, Baechler MF, Nanos GP $3^{\text {rd }}$, Forsberg JA, Potter BK. Traumatic and trauma-related amputations: part II: upper extremity and future directions. J Bone Joint Surg Am. 2010;92:2934-45.

19. Fletcher $\mathrm{C}$. Case report and literature review of the outcome following reimplantation of the arm. Trauma Surg Acute Care Open. 2017;2:e124.

20. Daoutis NK, Gerostathopoulos N, Efstathopoulos D, Misitzis D, Bouchlis G, Anagnostou S, et al. Major amputation of the upper extremity. Functional results after replantation/revascularization in 47 cases. Acta Orthop Scand Suppl. 1995;264:7-8. 